\title{
MODELING THE NEXUS BETWEEN ENTREPRENEURIAL MARKETING DIMENSIONS AND BUSINESS GROWTH AMONG SMALL AND MEDIUM AGRO-PROCESSING ENTERPRISES IN ZIMBABWE
}

\author{
Eugine Tafadzwa Maziriri $^{1 \bowtie}$, Miston Mapuranga ${ }^{2}$ \\ ${ }^{1}$ University of the Witwatersrand, South Africa \\ ${ }^{2}$ The Da Vinci Institute for Technology Management, South Africa
}

\begin{abstract}
This study aims to determine the relationship between entrepreneurial marketing dimensions and business growth among small and medium agro-processing enterprises in Zimbabwe. The methodology involved a quantitative approach to collecting and analyzing research data. The field study was conducted in Bindura, Zimbabwe to collect research data from 260 managers of agro-processing SMEs. Using the SPSS 24 and AMOS 24 software, the Structural Equation Modeling (SEM) procedure was performed to analyze the research data. The study's findings validate the assertion that dimensions such as product innovation, entrepreneurial orientation, risk-taking and resource leveraging are instrumental in stimulating business growth among agro-processing SMEs in Zimbabwe. A robust relationship was also found between resource leveraging and business growth. Moreover, managerial implications of the findings were discussed and limitations and future research directions were indicated
\end{abstract}

Keywords: product innovation, entrepreneurial orientation; risk-taking, resource leveraging, business growth

\section{INTRODUCTION}

In many developing countries, small and medium enterprises (SMEs) constitute the bulk of industrial base
(Wambugu et al., 2015). In addition, Singh et al. (2008) point out that SMEs play an increasingly important role as they address poverty by creating jobs; disperse economic activities in the countryside, and provide broadbased sources of growth. Agro-processing SMEs, in particular, contribute significantly to value-added creation, maximize the efficiency of resource allocation and enhance distribution by mobilizing and utilizing local human and physical resources (Wambugu et al., 2015). The agro-processing industry has the largest number of formally registered enterprises of the entire number of manufacturing firms and is dominated by small and medium enterprises (Kormawa et al., 2011). Agro-processing small and medium enterprises (SMEs) are critical in accelerating economic growth through employment generation, agricultural and non-agricultural income, value addition, regional industrial performance and distribution of local and material resources (Wanjau et al., 2016). Yet agro-processing SMEs are characterized by limited technological capacity, low product diversification, lack of flourishing entrepreneurship activities and low value addition (Wanjau et al., 2016).

Despite the contributions offered by agro-processing SMEs to the agricultural sector, it is imperative to note that various authors have investigated on SMEs

\footnotetext{
$\bowtie$ MBA Eugine Tafadzwa Maziriri, School of Economic and Business Sciences, University of the Witwatersrand, Johannesburg. Private Bag 3, WITS, 2050, South Africa, e-mail: eugine.maziriri@wits.ac.za, https://orcid.org/0000-0002-8047-4702
} 

among small and medium agro-processing enterprises in Zimbabwe. J. Agribus. Rural Dev., 2(48), 153-163. http://dx.doi. org/10.17306/J.JARD.2018.00407

in various contexts by focusing on challenges faced by SMEs in Zimbabwe (Gombarume and Mavhundutse, 2014); determinants of small and medium enterprises failure in Zimbabwe (Chigusiwa et al., 2011); evaluation of the factors affecting growth of SMEs in Zimbabwe (Chiwara, 2016); the influence of innovation on the performance of SMEs in Zimbabwe (Makanyeza and Dzvuke, 2015); SMEs policies and challenges: a comparative analysis of Zimbabwe and South Korea (Majoni et al., 2016); and ICT adoption and use in Zimbabwean SMEs (Makiwa and Steyn, 2016). Based on the aforementioned elucidations, it can be noted that there is a lacuna in studies which fail to address the nexus between entrepreneurial marketing dimensions and business growth among agro-processing SMEs in Zimbabwe. Therefore, on the academic side, this study makes a significant contribution to the entrepreneurial marketing and agri-business literature by systematically exploring the impact of entrepreneurial marketing dimensions on the business growth of Zimbabwean agro-processing SMEs. Overall, the current study findings will provide tentative support to the proposition that product innovation, entrepreneurial orientation, risk-taking and resource leveraging should be recognized as significant antecedents for intensifying business growth of agro-processing SMEs in Zimbabwe. Therefore, this study stands to immensely contribute new knowledge to the existing body of entrepreneurial marketing and agri-business in Africa - a context that is often most neglected by some researchers in developing countries.

In the subsequent sections of this paper, the authors outline the main objective as well as research questions, the theoretical framework of this study, a delineation of pragmatic literature sourced from the work of authors who have conducted similar investigations, a conceptualized model customized for this study including hypotheses, research methods and approach adopted by the study, and a discussion of the findings unearthed through the process of investigation.

\section{PRIMARY OBJECTIVE AND RESEARCH QUESTIONS OF THE STUDY}

\section{Primary objective}

- To determine the impact of entrepreneurial marketing dimensions on the business growth of agro-processing SMEs in Zimbabwe.
Specific research questions

- Does product innovation have a positive impact on the business growth of agro-processing SMEs in Zimbabwe?

- To what extent does entrepreneurial orientation impact the business growth of agro-processing SMEs in Zimbabwe?

- Does risk-taking have a positive impact on the business growth of agro-processing SMEs in Zimbabwe?

- To what extent does entrepreneurial orientation impact the business growth of agro-processing SMEs in Zimbabwe?

\section{EMPIRICAL LITERATURE}

This section presents a review of the literature related to the purpose of this study.

\section{Entrepreneurial marketing dimensions}

Entrepreneurial marketing includes an innovation and entrepreneurial process requiring a creative approach, like leveraging the resources which enable businesses to produce more output using fewer inputs (Yang and Gabrielsson, 2017). Ionitã (2012) defines entrepreneurial marketing dimensions as a proactive identification and exploitation of opportunities for obtaining and retaining profitable strategies through innovative approaches that limit risk and loss. Such dimensions as resource leveraging and value creation are the optimal strategies that a business can employ. This study identifies the underlying dimensions of entrepreneurial marketing based on a review of empirical studies published in marketing and entrepreneurship journals, and on the characteristics of entrepreneurial marketing dimensions suggested by Jones and Rowley (2011), Rezvani and Khazaei (2013) as well as Hallbäck and Gabrielsson (2013). The authors found that entrepreneurial marketing can be classified into different categories, including product innovation, entrepreneurial orientation, risk-taking and resource leveraging. All dimensions are closely interrelated and encompass all important elements that were suggested in prior research as essential elements of entrepreneurial marketing. As a result, this study focused on product innovation, entrepreneurial orientation, risk-taking and resource leveraging - these are the dimensions under investigation in this paper. Furthermore, these entrepreneurial marketing dimensions were hypothesized to have 
Maziriri, E. T., Mapuranga, M. (2018). Modeling the nexus between entrepreneurial marketing dimensions and business growth among small and medium agro-processing enterprises in Zimbabwe. J. Agribus. Rural Dev., 2(48), 153-163. http://dx.doi. org/10.17306/J.JARD.2018.00407

a positive and significant impact on business growth. They are fully investigated and tested later in this study.

\section{Product innovation and entrepreneurial orientation}

Innovation is described as the introduction of new or improved processes, products or services based on new knowledge that may be scientific or technological (Schneider, 2015). Product innovation refers to the capability of organizations to introduce new products and features (Koufteros et al., 2005). Product innovation encompasses both product improvements (i.e., minor changes to an existing product) and new product development (Zaefarian et al., 2017). On the other hand, entrepreneurial orientation refers to a business' strategic orientation and captures specific entrepreneurial aspects of decision-making styles, methods, and practices; as such it reflects how a business operates rather than what it does (Wiklund and Shepherd, 2003). An entrepreneurial orientation is defined as "the processes, practices, and decision-making activities that lead to new entry" (Wang et al., 2017), including innovative, proactive, and risk-taking decisions and behaviors (Covin and Lumpkin, 2011). As a business-level concept, an entrepreneurial orientation is an antecedent to new entry but may be insufficient to generate economic returns (Wang et al., 2017). Moreover, Stam and Elfring (2008) point out that that, to create value from an entrepreneurial orientation, firms need to possess needed resources and essential capabilities.

\section{Risk-taking and resource leveraging}

Hnilica and Fotr (2009) defines business risk-taking as an opportunity which carries uncertainty, the outcome of which could either be positive or negative to the business strategic goals. Lumpkin and Dess (1996) elaborate that risk-taking represents a willingness to commit resources to implement projects, activities, and solutions that contain inherently high levels of uncertainty regarding the likely outcomes. The concept of risk-taking has also been referred to as being prepared to take bold actions by pursuing the unknown, and to make uncertain resource commitments in an attempt to achieve strategic business goals (Morgan et al., 2015). Furthermore, it is imperative to start by elucidating what are resources before discussing the meaning of resource leveraging. Sok et al. (2016) define resources as the business' controlled tangible assets that can be quantified, valued, and traded, and intangible assets that are embedded in the business' culture or protected by legal property rights. On the other hand, leveraging, at its most basic level, refers to doing more with less (Morris et al., 2002). Thus, resource leveraging is viewed as the comprehensive process of structuring a business' resource portfolio to build capabilities that will create and maintain business value (Sirmon et al., 2007). Sirmon et al. (2007) are also of the view that effective leveraging involves learning how to apply a business' market segment-oriented expertise established by leveraging its capabilities to meet further expectations from customers in that market segment.

\section{Business growth}

Growth determinants of small businesses can be classified by many factors: individual, organizational, and environmental, the factor of organizational resources, the competence of the company, organizational culture and structure (Sarwoko and Frisdiantara, 2016). Davidsson et al. (2008) describe business growth as the very essence of entrepreneurship. The growth of SMEs is determined by the owner/manager characteristics (personal approach), and how the strategy is taken (managerial approach) (Sarwoko and Frisdiantara, 2016). Additionally, Baum et al. (2001) maintain that although several studies have analyzed the elements of business growth, each factor was analyzed separately, and focus was only placed on personal features, organizational factors, and strategies. Baum et al. (2001) further concluded that the environment is a factor that also influences the growth of SMEs because growth is uncertain, due to environmental conditions such as competitive conditions and changing market dynamics.

\section{CONCEPTUAL FRAMEWORK AND HYPOTHESIS DEVELOPMENT}

Drawing from the literature reviewed, the research model in Fig. 1 has been developed. The conceptual model is a representation of the constructs and their relationships with one another.

\section{HYPOTHESES DEVELOPMENT}

The following section includes an in-depth discussion of the development of hypotheses for the current study. 


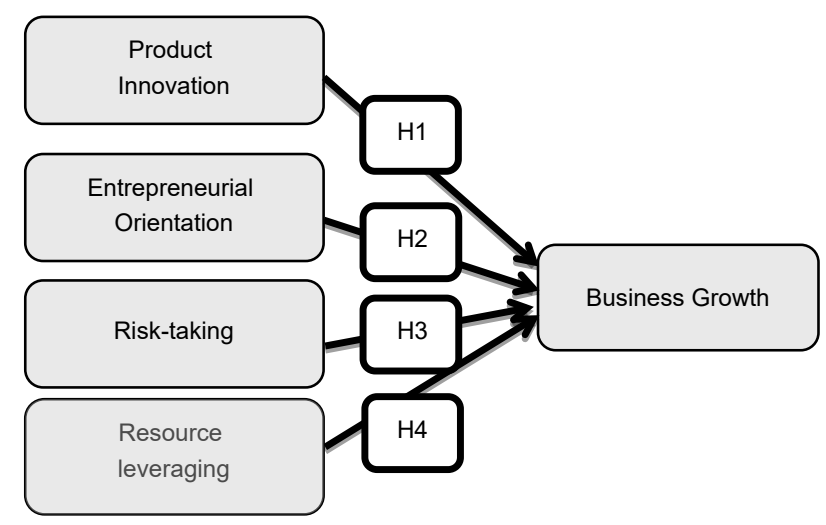

Fig. 1. Conceptual model Source: own research.

\section{Product innovation and business growth}

Dekoulou and Trivellas (2017) conducted a study that focused on the nexus of product innovation and business growth. The study revealed that product innovation has a positive and significant impact on business growth. In addition, Koufteros et al. (2014) concur that product innovation practices are said to be forerunners to business growth. Hult (2011) also attested to this concept when he alluded to how product innovation lays a foundation for a business' success and growth. A wealth of evidence indicates a positive relationship between innovation and business growth in both manufacturing and consumption of products and services (Roper et al., 2008). Therefore, it can be hypothesized that:

\section{H1: Product innovation has a positive impact on business growth.}

\section{Entrepreneurial orientation and business growth}

Grinstein (2008) determines that entrepreneurial orientation of a business allows it to capitalize on emerging opportunities, and hence is an important driver of new products and business growth. Grande et al. (2011) alludes that entrepreneurial orientation has been widely recognized by researchers as a business construct that determines its performance (Grande et al., 2011). Semrau et al. (2015) conclude that SMEs with an entrepreneurial strategic position actively introduce new solutions and offer different products and services to stay on top of the market. Based on the abovementioned discussion, it can be noted that a positive and significant relationship exists between entrepreneurial orientation and business growth. Therefore, it can be hypothesized that:
$\mathrm{H} 2$ : Entrepreneurial orientation has a positive impact on business growth

\section{Risk-taking and business growth}

It is imperative to discuss on the nexus between risktaking and business growth. Lotz and Van Der Merwe (2013) explicate that risk-taking has been associated with strategic decision making as the future is not guaranteed. Subsequently, the element of risk-taking is embedded in strategic decisions which improve business performance. Businesses are supposed to embrace the concept of risk-taking as their growth can be characterized by such events (Morris et al., 2008). Kreiser et al. (2013) are of the view that businesses that take risks are said to be more decisive and are able to make strategic decisions more timely which improve their overall of performance and growth. Avlonitis and Salavou (2007) conclude that businesses aggressively involved in risktaking as prospectors and pioneers are likely to be the first to realize business growth and capture a huge market share in their segments. Therefore, deducing from the aforementioned deliberations, it can be hypothesized that:

\section{H3: Risk-taking has a positive impact on business growth}

\section{Resource leveraging and business growth}

Campbell and Park (2016) conducted a study that investigated the relationship between resource leveraging and business growth. Their findings pointed to the fact that resource leveraging has a positive and significant impact on business growth. Anderson and Eshima (2013) argue that in the SME context, tangible resources tend to be constrained. Thus, the intangible resources such as intellectual property, brand identity, and reputation have to take on particular strategic significance in order to maximize business growth. Sok et al. (2016) concur that SMEs need to have resources and capabilities that are at superior level and there has to be synergy between intellectual capacity and physical resources as this will assist in gaining 

among small and medium agro-processing enterprises in Zimbabwe. J. Agribus. Rural Dev., 2(48), 153-163. http://dx.doi. org/10.17306/J.JARD.2018.00407

superior financial performance and thus achieve business growth. Villanueva et al. (2012) alludes that leveraging on resources which are valuable, scarce, unique and non-substitutable facilitates business performance. According to O'Cass and Sok (2013), if a combination of intellectual resources and physical resources is strategically applied and innovation is the ultimate modus operandi, then the business grows faster. Therefore, it can be hypothesized that:

\section{H4: Resource leveraging has a positive impact on business growth}

\section{RESEARCH METHODOLOGY}

The study relied on a quantitative research design with a structured questionnaire. The design was suitable to solicit the required information relating to product innovation, entrepreneurial orientation, risk-taking, resource leveraging and business growth. In addition, the approach allows to examine the causal relationships with the constructs used in the study.

\section{Sample and data collection}

The data for this research was collected from agro-processing SMEs within the agriculture sector of Mashonaland Central province in Zimbabwe. Precisely, the target population was restricted to managers and owners of agro-processing SMEs operating in the rural area of Bindura. The database of rural SMEs (small businesses) was obtained from the Bindura Rural District Council (BRDC). The study used a simple random probability sampling method. This technique best suited the study as it provided a fair opportunity for each respondent to be chosen: every name within the list of SMEs registered with the Bindura Rural District Council (BRDC) had an equal chance of selection. The questionnaires clearly stated that the anonymity of participants would be guaranteed and that the study was purely for academic purposes. Of the 300 questionnaires distributed, 260 were returned. The questionnaires were usable, yielding a response rate of 87 percent.

\section{Research instrumentation and questionnaire design}

The instruments developed for this research were based on previous studies. Proper modifications were made to fit the current research context and purpose. Two trained fieldworkers distributed the self-administered questionnaire. Section A requested the respondents to provide their demographic profile. Product innovation was measured using a six-item scale adapted from Avlonitis and Salavou (2007). In addition, entrepreneurial orientation was measured using an eight-item scale adapted from Atuahene-Gima and Ko (2001). Furthermore, risk-taking was measured using a three-item scale also adapted from Avlonitis and Salavou (2007). Resource leveraging was measured using a seven-item scale adapted from Becherer et al. (2012). Moreover, business growth was measured using a nine-item scale adapted from Lotz and van der Merwe (2013) as well as Tan et al. (1998). All were measured on a fivepoint Likert scale, ranging from 1 (strongly disagree) to 5 (strongly agree) in order to express the degree of agreement.

\section{Respondent profile}

Most participants were males, representing 56.9\% $(n=148)$, while female participants were represented by $43.1 \%(n=112)$. Most participants were in the age bracket of $40-49$, representing $32.3 \%(n=84)$ of the total sample, followed by the age brackets of 50-59 $(31.2 \%, n=81), 30-39(16.9 \%, n=44), 60$ and above $(12.3 \%, n=32)$, and $18-29(7.3 \%, n=19)$. Most participants had 51-100 employees, representing 37.3\% $(n=97)$ of the total population surveyed, followed by those who had $101-200(30.8 \%, n=80)$, those who had 201 and above employees $(18.1 \%, n=47)$ and finally those who had $1-10$ employees $(3.8 \%, n=10)$.

\section{RELIABILITY AND VALIDITY}

Reliability was assessed through Cronbach's alpha and composite reliabilities (CR). All the reliability values (Table 1) were above the recommended value of 0.7 (Malhotra, 2010), suggesting excellent levels of internal consistency.

In Table 1, all the individual item loadings exceeded the recommended value of 0.5 (Anderson and Gerbing, 1988). This indicates that all the measurement instruments are acceptable and reliable since all the individual items converged well, with more than 50 percent of each item's variance shared with its respective construct (Fraering and Minor, 2006). 
Maziriri, E. T., Mapuranga, M. (2018). Modeling the nexus between entrepreneurial marketing dimensions and business growth among small and medium agro-processing enterprises in Zimbabwe. J. Agribus. Rural Dev., 2(48), 153-163. http://dx.doi. org/10.17306/J.JARD.2018.00407

Table 1. Measurement accuracy assessment

\begin{tabular}{|c|c|c|c|c|c|c|c|c|}
\hline \multirow{2}{*}{\multicolumn{2}{|c|}{$\begin{array}{l}\text { Research } \\
\text { constructs }\end{array}$}} & \multicolumn{2}{|c|}{ Scale item } & \multicolumn{2}{|c|}{ Cronbach's test } & \multirow{3}{*}{$\mathrm{CR}$} & \multirow{2}{*}{ AVE } & \multirow{3}{*}{$\begin{array}{c}\begin{array}{c}\text { Factor } \\
\text { loadings }\end{array} \\
0.609\end{array}$} \\
\hline & & \multirow{2}{*}{$\begin{array}{c}\text { mean } \\
3.52\end{array}$} & \multirow{2}{*}{$\begin{array}{c}\text { SD } \\
0.889\end{array}$} & \multirow{2}{*}{$\begin{array}{c}\text { item-total } \\
0.092\end{array}$} & \multirow[t]{2}{*}{$\alpha$ value } & & & \\
\hline PI & PI 1 & & & & & & \multirow{6}{*}{0.71} & \\
\hline & PI 2 & 3.64 & 0.819 & 0.158 & \multirow{5}{*}{0.837} & \multirow{5}{*}{0.94} & & 0.904 \\
\hline & PI 3 & 3.58 & 0.841 & 0.174 & & & & 0.829 \\
\hline & PI 4 & 3.46 & 0.964 & 0.157 & & & & 0.756 \\
\hline & PI 5 & 3.39 & 1.104 & 0.116 & & & & 0.945 \\
\hline & PI 6 & 3.20 & 0.962 & 0.344 & & & & 0.969 \\
\hline \multirow[t]{8}{*}{ EO } & EO 1 & 3.52 & 1.082 & 0.206 & \multirow{8}{*}{0.615} & \multirow{8}{*}{0.93} & \multirow{8}{*}{0.64} & 0.909 \\
\hline & $\mathrm{EO} 2$ & 3.64 & 1.141 & 0.198 & & & & 0.807 \\
\hline & EO 3 & 3.58 & 0.870 & 0.123 & & & & 0.894 \\
\hline & EO 4 & 3.46 & 0.995 & 0.047 & & & & 0.609 \\
\hline & EO 5 & 3.39 & 0.982 & 0.194 & & & & 0.825 \\
\hline & EO 6 & 3.20 & 0.819 & 0.262 & & & & 0.595 \\
\hline & EO 7 & 3.22 & 0.901 & 0.264 & & & & 0.810 \\
\hline & EO 8 & 3.10 & 0.828 & 0.260 & & & & 0.879 \\
\hline \multirow[t]{3}{*}{ RT } & RT1 & 3.40 & 0.790 & 0.219 & & & & 0.885 \\
\hline & RT 2 & 3.51 & 0.761 & 0.248 & 0.672 & 0.88 & 0.71 & 0.796 \\
\hline & RT 3 & 3.52 & 0.786 & 0.280 & & & & 0.845 \\
\hline \multirow[t]{7}{*}{$\mathrm{RL}$} & RL 1 & 3.58 & 0.783 & 0.015 & & & & 0.749 \\
\hline & RL 2 & 3.58 & 0.762 & 0.211 & & & & 0.855 \\
\hline & RL 3 & 3.56 & 0.754 & 0.156 & & & & 0.708 \\
\hline & RL 4 & 3.51 & 0.756 & 0.149 & 0.653 & 0.92 & 0.62 & 0.833 \\
\hline & RL 5 & 3.40 & 0.829 & 0.136 & & & & 0.557 \\
\hline & RL 6 & 3.47 & 0.839 & 0.266 & & & & 0.868 \\
\hline & RL 7 & 3.52 & 0.806 & 0.315 & & & & 0.597 \\
\hline \multirow[t]{9}{*}{$\mathrm{BG}$} & BG 1 & 3.70 & 0.809 & 0.194 & & & & 0.852 \\
\hline & BG 2 & 3.71 & 0.762 & 0.238 & & & & 0.717 \\
\hline & BG 3 & 3.63 & 0.775 & 0.257 & & & & 0.696 \\
\hline & BG 4 & 3.51 & 0.740 & 0.366 & & & & 0.878 \\
\hline & BG 5 & 3.53 & 0.745 & 0.348 & 0.820 & 0.94 & 0.62 & 0.775 \\
\hline & BG 6 & 3.49 & 0.771 & 0.279 & & & & 0.659 \\
\hline & BG 7 & 3.48 & 0.988 & 0.336 & & & & 0.875 \\
\hline & BG 8 & 3.64 & 0.882 & 0.193 & & & & 0.769 \\
\hline & BG 9 & 3.78 & 0.885 & 0.223 & & & & 0.826 \\
\hline
\end{tabular}

Source: own research.

Note: $\mathrm{PI}=$ product innovation; $\mathrm{EO}=$ entrepreneurial orientation; $\mathrm{RT}=$ risk-taking; $\mathrm{RL}=$ resource leveraging; $\mathrm{BG}=$ business growth; $\mathrm{SD}=$ standard deviations; $\mathrm{AVE}=$ average variance extracted; $\mathrm{CR}=$ composite reliability. 
Maziriri, E. T., Mapuranga, M. (2018). Modeling the nexus between entrepreneurial marketing dimensions and business growth among small and medium agro-processing enterprises in Zimbabwe. J. Agribus. Rural Dev., 2(48), 153-163. http://dx.doi. org/10.17306/J.JARD.2018.00407

As shown by the results in Table 1, the lowest composite reliability (CR) value of 0.88 is well above the recommended 0.6 (Hulland, 1999), while the lowest obtained average variance extracted (AVE) value of 0,49 is also above the recommended level of 0.40 , indicating a satisfactory measure (Anderson and Gerbing, 1988, p. 411). This means that convergent validity was achieved.

\section{Correlation analysis}

In order to establish the relationship between the variables in the study, nonparametric (Spearman's) correlation was undertaken. The inter-construct correlation matrix was also used to assess the validity of measurement instruments, more specifically discriminant validity. Correlations among constructs were evaluated to see if they were lower than 2 . The higher the correlation between variables, the lower the validity of those variables. The inter-construct values are required to be below 0.6 or, in some cases, below 0.85 to indicate discriminant validity. According to Table 2 below, most of the values are below 0.6 which confirms the presence of discriminant validity.

Table 2. Correlation between the constructs

\begin{tabular}{cccccc}
\hline $\begin{array}{c}\text { Research } \\
\text { constructs }\end{array}$ & PL & EO & RT & RL & BG \\
\hline PI & 1 & & & & \\
EO & $0.124^{*}$ & 1 & & & \\
RT & $0.129^{*}$ & $0.225^{* *}$ & 1 & & \\
RL & $0.168^{* *}$ & 0.104 & $0.201^{* *}$ & 1 & \\
BG & $0.190^{* *}$ & $0.228^{* *}$ & 0.115 & $0.188^{* *}$ & 1 \\
\hline
\end{tabular}

See explanations under Table 1.

Source: own research.

\section{Model fitting results}

The model's goodness of fit was assessed through confirmatory factor analysis (CFA). Recommended statistics for the final overall model assessment showed an acceptable fit of the measurement model to the data; that is: $(\mathrm{CMIN} / \mathrm{DF})=2.38$, Tucker and Lewis index $(\mathrm{TLI}>$ $90)=0.933$, incremental index of fit $($ IFI $>90)=0.935$, comparative fit index $(\mathrm{CFI}>0.90)=0.948$ and root mean square error of approximation $($ RMSEA $<0.08)=0.064$ (Schreiber et al., 2006).

\section{STRUCTURAL MODEL ASSESSMENT AND HYPOTHESIS TESTING}

The results for CFA are good. Therefore, Structural Equation Modeling (SEM) was performed subsequently. The hypotheses testing by path modeling was done to determine the strength or weakness of the causal relationships. The results of the structural model analysis indicated that all the structural models fit statistics within the tolerable ranges, i.e., $\chi^{2} /(\mathrm{df})=2.526$, $\mathrm{NFI}=0.918, \mathrm{IFI}=0.914, \mathrm{TLI}=0.912, \mathrm{CFI}=0.948$, and RMSEA $=0.064$.

Table 3. Results of the structural equation model analysis

\begin{tabular}{lcccl}
\hline $\begin{array}{c}\text { Hypoth- } \\
\text { esized } \\
\text { relationship }\end{array}$ & Hypothesis & $\begin{array}{c}\text { Path } \\
\text { coefficient }\end{array}$ & $P$ value & Outcome \\
\hline $\mathrm{PI} \rightarrow$ BG & H1 & 0.240 & $0.000^{* * * *}$ & $\begin{array}{l}\text { Positive and } \\
\text { significant }\end{array}$ \\
$\mathrm{EO} \rightarrow$ BG & H2 & 0.124 & $0.000^{* * *}$ & $\begin{array}{l}\text { Positive and } \\
\text { significant }\end{array}$ \\
$\mathrm{RT} \rightarrow$ BG & H3 & 0.147 & $0.000^{* * *}$ & $\begin{array}{l}\text { Positive and } \\
\text { significant }\end{array}$ \\
$\mathrm{RL} \rightarrow \mathrm{BG}$ & H4 & 0.557 & $0.000^{* * * *}$ & $\begin{array}{l}\text { Positive and } \\
\text { significant }\end{array}$ \\
\hline
\end{tabular}

See explanations under Table 1.

$* * *$ Significance level $<0.001, * *$ significance level $<0.01, *$ significance level $<0.1$.

Source: own research

\section{DISCUSSION OF RESULTS}

\section{Product Innovation (PI) and Business \\ Growth (BG) - H1}

According to the proposed hypothesis statement, product innovation has a positive impact on business growth. The research findings show that not only is this statement supported, but it is also significant at the $99 \%$ confidence level $(P<0.001)$. The path coefficient is 0.240 implying that it is positive and supported. Ultimately, the research findings show that product innovation has an impact on business growth. Therefore, this study fails to reject $\mathrm{H} 1$. These results are in line with literature 

among small and medium agro-processing enterprises in Zimbabwe. J. Agribus. Rural Dev., 2(48), 153-163. http://dx.doi. org/10.17306/J.JARD.2018.00407

whereby Love and Roper (2015) emphasize that innovation continues to be recognized as an essential element of competition and dynamic efficiency of businesses. In addition, it is evident that product innovators take market share from non-innovators and achieve business growth at their expense (Love and Roper, 2015). As such, product innovation is seen to result in faster growth, more efficiencies and, ultimately, more profitability (Love and Roper, 2015).

\section{Entrepreneurial Orientation (EO) and Business Growth (BG) - H2}

Based on the proposed hypothesis statement, EO has a significant and positive impact on BG. The research findings show that this hypothesis is supported as well as significant at the $99 \%$ confidence level $(P<0.001)$. The path coefficient is 0.124 indicating that the relationship between EO and BG is positive and supported. Holistically, the research findings imply that entrepreneurial orientation has a strong impact on business growth Therefore, this study fails to reject $\mathrm{H} 2$. It is vital to note that these results concur with the works of Avlonitis and Salavou (2007) who concluded that the entrepreneurial orientation of SMEs has a positive relationship with business growth.

\section{Risk-Taking (RT) and Business Growth (BG) $-\mathrm{H} 3$}

According to the proposed hypothesis statement, risktaking has a positive impact on business growth. The research findings show that not only is this statement supported, but it is also significant at the $99 \%$ confidence level $(P<0.001)$. The path coefficient is 0.147 implying that it is positive and supported. Ultimately, the research findings show that risk-taking has an impact on business growth. Therefore, this study fails to reject H3. It is also imperative to mention that these results are in line with the works of Peng (2015) who examined the relationship between risk-taking and firm performance of small and medium-sized enterprises and large private firms. The results revealed that risk-taking has a statistically and economically significant effect on corporate growth (Peng, 2015).

\section{Resource Leveraging (RL) and Business Growth (BG) - H4}

According to the proposed hypothesis statement, resource leveraging has a positive impact on business growth. The research findings show that not only is this statement supported, but it is also significant at the $99 \%$ confidence level $(P<0.001)$. The path coefficient is 0.557 implying that it is positive and supported. Ultimately, the research findings show that resource leveraging has an impact on business growth. Therefore, this study fails to reject $\mathrm{H} 3$. These results are in line with the relevant literature. For instance, Bruneel et al. (2009) explicated that researchers using the resource-based perspective have established a link between the extent to which firms own or leverage resources and their business growth. A common finding in these studies is the influence of the entrepreneurial team's experience on spurring the growth of the firm (Heirman and Clarysse, 2005). Arguably, resources are only one part of the story. Firms employ resources to attain organizational goals, i.e. they deploy a strategy. Besides resources, the strategy of entrepreneurial firms has an important influence on their subsequent growth (Bruneel et al., 2009).

\section{ACADEMIC AND PRACTICAL IMPLICATIONS FOR THE STUDY}

The present study offers implications for academicians. For example, an investigation of the research findings indicates that product innovation and business growth have a strong influence on each other, as indicated by a path coefficient of (0.240). Therefore, for academicians in the field of entrepreneurship and agri-business, this finding enhances the understanding of the relationship between product innovation and business growth as it provides a useful contribution to existing literature on these two variables. On the practitioners' side, the implications of these findings may be beneficial to the managers of agro-processing SMEs in Zimbabwe. For example, given the robust relationship between resource leveraging and business growth (0.557), managers within agro-processing SMEs in Zimbabwe ought to pay attention to, or highly engage in, resource leveraging so as to improve the business growth of their agro-processing entrepreneurial ventures within the agricultural sector.

\section{LIMITATIONS AND FUTURE RESEARCH SUGGESTIONS}

This study has several limitations which should be highlighted. Firstly, with a relatively small sample size, 
Maziriri, E. T., Mapuranga, M. (2018). Modeling the nexus between entrepreneurial marketing dimensions and business growth among small and medium agro-processing enterprises in Zimbabwe. J. Agribus. Rural Dev., 2(48), 153-163. http://dx.doi. org/10.17306/J.JARD.2018.00407

the findings cannot be assertively generalized, even though a number of demographic questions were used in an effort to determine how representative the sample was of the defined target population. In future research, a wider population including several agro-processing SMEs should be studied. All the data in the study was collected quantitatively, which led to the common method bias inherent to quantitative methods. Future studies may attempt to focus on triangulation methods to avoid this bias. Also, future research scholars can investigate the use of mobile technologies, cloud computing and motivation strategies as antecedents to the business performance of agro-processing SMEs. Furthermore, comparative studies between the results of this study and those obtained from other firms in different sectors or through meta-analyses could also be considered in the future. This could lead to other thoughtprovoking insights that were not captured in the present study.

\section{CONCLUSION}

This study was conducted with the intent to investigate the nexus between entrepreneurial marketing dimensions and business growth among agro-processing SMEs in Zimbabwe. In addition, the study validates that factors such as product innovation, entrepreneurial orientation, risk-taking and resource leveraging are instrumental in stimulating business growth among Zimbabwean agro-processing SMEs. A robust relationship was also found between resource leveraging and business growth. The results support all the postulated hypotheses. Managerial implications of the findings were discussed and limitations and future research directions were indicated. Above and beyond, this study will immensely contribute new knowledge to the existing body of entrepreneurship and agri-business in the African setting - a research context which happens to be neglected in academics.

\section{ACKNOWLEDGEMENTS}

The authors express gratitude to the Ministry of Small and Medium Enterprises and Cooperative Development in Zimbabwe for their financial support for the accomplishment of the research.

\section{REFERENCES}

Anderson, B. S., Eshima, Y. (2013). The influence of firm age and intangible resources on the relationship between entrepreneurial orientation and firm growth among Japanese SMEs. J. Bus. Ventur., 28(3), 413-429.

Anderson, J. C., Gerbing, D. W. (1988). Structural equation modelling in practice: A review and recommended a twostep approach. Psych. Bull., 103(3), 411-415.

Atuahene-Gima, K., Ko, A. (2001). An empirical investigation of the effect of market orientation and entrepreneurship orientation alignment on product innovation. Org. Sci., 12(1), 54-74.

Avlonitis, G. J., Salavou, H. E. (2007). Entrepreneurial orientation of SMEs, product innovativeness, and performance. J. Bus. Res., 60(5), 566-575.

Baum, J. R., Locke, E. A., Smith, K. G. (2001). A multidimensional model of venture growth. Acad. Manag. J., 44(2), 292-303.

Becherer, R. C., Helms, M. M., McDonald, J. P. (2012). The effect of entrepreneurial marketing on outcome goals in SMEs. New Eng. J. Entrep., 15(1), 7-18.

Bruneel, J., Clarysse, B., Wright, M. (2009). Linking entrepreneurial strategy and firm growth (No. 09/571). Ghent University, Faculty of Economics and Business Administration.

Chigusiwa, L., Bindu, S., Mudavanhu, V., Muchabaiwa, L., Mazambani, D. (2011). Export-led growth hypothesis in Zimbabwe: Does export composition matter? Int. J. Econ. Res., 2(4), 111-129.

Chiwara, O. M. (2016). An evaluation of the factors affecting the growth of small and medium enterprises (SMEs) in Zimbabwe: A case study of SMEs in Harare (2009-2015). Master of Business Administration dissertation. University of Zimbabwe.

Covin, J. G., Lumpkin, G. T. (2011). Entrepreneurial orientation theory and research: Reflections on a needed construct. Entrep. Theory Pract., 35(5), 855-872.

Davidsson, P., Steffens, P. R., Fitzsimmons, J. R. (2008). Performance assessment in entrepreneurship and management research: Is there a pro-growth bias. QUT Business School. 1-8.

Dekoulou, P., Trivellas, P. (2017). Organizational structure, innovation performance and customer relationship value in the Greek advertising and media industry. J. Bus. Indust. Market., 32(3), 385-397.

Fraering, M., Minor, M. S. (2006). Virtual Community in Financial Institutions: Development of the Virtcomm Scale. Market. Manag. J., 16(2), 1-14. 
Maziriri, E. T., Mapuranga, M. (2018). Modeling the nexus between entrepreneurial marketing dimensions and business growth among small and medium agro-processing enterprises in Zimbabwe. J. Agribus. Rural Dev., 2(48), 153-163. http://dx.doi. org/10.17306/J.JARD.2018.00407

Gombarume, F., Mavhundutse, S., (2014). Challenges Faced by Small to Medium Scale Enterprises: A Case Study of Chitungwiza, Zimbabwe. Green. J. Bus. Manag. Stud., 4(4), 103-107.

Grande, J. (2011). Entrepreneurial efforts and change in rural firms: three case studies of farms engaged in on-farm diversification. The Handbook of Research on Entrepreneurship in Agriculture and Rural Development (p. 74-93).

Grande, J., Madsen, E. L., Borch, O. J. (2011). The relationship between resources, entrepreneurial orientation and performance in farm-based ventures. Entrep. Reg. Dev., 23(3-4), 89-111.

Grinstein, A. (2008). The relationships between market orientation and alternative strategic orientations: A meta-analysis. Eur. J. Market., 42(1/2), 115-134.

Hallbäck, J., Gabrielsson, P. (2013). Entrepreneurial marketing strategies during the growth of international new ventures originating in small and open economies. Int. Bus. Rev., 22(6), 1008-1020.

Heirman, A., Clarysse, B. (2005). The Imprinting Effect Of Initial Resources And Market Strategy On The Early Growth Path Of Start-Ups. In: Academy of Management Proceedings, 1, pp. A1-A6). Briarcliff Manor, NY 10510: Academy of Management.

Hnilica, J., Fotr, J. (2009), Aplikovaná analýza rizika ve finanpním managementu a investipním rozhodování. Praha: Grada.

Hulland, J. (1999). Use of partial least squares (PLS) in strategic management research: A review of four recent studies. Strat. Manag. J., 195-204.

Hult, G. T. M. (2011). Market-focused sustainability: market orientation plus! J. Acad. Market. Sci, 39(1), 1-6.

Ionitã, D. (2012). Entrepreneurial marketing: a new approach for challenging times. Manag. Market., 7(1), 131.

Jones, R., Rowley, J. (2011). Entrepreneurial marketing in small businesses: A conceptual exploration. Int. Small Bus. J., 29(1), 25-36.

Koufteros, X., Lu, G., Peters, R. C., Lai, K. H., Wong, C. W., Cheng, T. E. (2014). Product development practices, manufacturing practices, and performance: A mediational perspective. Int. J. Prod. Econ., 156, 83-97.

Koufteros, X., Vonderembse, M., Jayaram, J. (2005). Internal and external integration for product development: the contingency effects of uncertainty, equivocality, and platform strategy. Dec. Sci., 36(1), 97-133.

Kormawa, P. M., Wohlmuth, K., Devlin, J. (2011). Agribusiness for Africa's prosperity: Country case studies. Working Paper. ( $\left.2^{\text {nd }} E d.\right)$. Vienna: UNIDO.

Kreiser, P. M., Marino, L. D., Kuratko, D. F., Weaver, K. M. (2013). Disaggregating entrepreneurial orientation: the non-linear impact of innovativeness, proactiveness and risk-taking on SME performance. Small Bus. Econ., 40(2), 273-291.

Lotz, H. M., van der Merwe, S. P. (2013). An investigation of the influence of entrepreneurial orientation on the perceived success of agribusinesses in South Africa. South Afr. J. Bus. Manag., 44(1), 15-32.

Love, J. H., Roper, S. (2015). SME innovation, exporting and growth: A review of existing evidence. Int. Small Bus. J., 33(1), 28-48.

Lumpkin, G. T., Dess, G. G. (1996). Clarifying the entrepreneurial orientation construct and linking it to performance. Acad. Manag. Rev., 21(1), 135-172.

Majoni, T., Matunhu, J., Chaderopa B. (2016). SMEs Policies and Challenges: A Comparative Analysis of Zimbabwe and South Korea. Int. J. Sci. Res. Pub., 6(6), 380-381.

Makanyeza, C., Dzvuke, G. (2015). The influence of innovation on the performance of small and medium enterprises in Zimbabwe. J. Afr. Bus., 16(1-2), 198-214.

Makiwa, P. J., Steyn, R. (2016). ICT adoption and use in Zimbabwean SMEs. In IST-Africa Week Conference, 2016 (pp. 1-8). IEEE.

Malhotra, N. K. 2010. Marketing research: an applied orientation. New Jersey: Prentice Hall.

Morgan, T., Anokhin, S., Kretinin, A., Frishammar, J. (2015). The dark side of the entrepreneurial orientation and market orientation interplay: A new product development perspective. Int. Small Bus. J., 33(7), 731-751.

Morris, M. H., Schindehutte, M., LaForge, R. W. (2002). Entrepreneurial marketing: a construct for integrating emerging entrepreneurship and marketing perspectives. J. Market. Theory Pract., 10(4), 1-19.

Morris, M. H., Kuratko, D. F. Covin, J. G. 2008. Corporate entrepreneurs and innovation. 2nd Edition. Mason, $\mathrm{OH}$ : South-Western.

O'Cass, A., Sok, P. (2013). Exploring innovation driven value creation in B2B service firms: The roles of the manager, employees, and customers in value creation. J. Bus. Res., 66(8), 1074-1084.

Peng, X. U. (2015). Risk Taking and Firm Growth. RIETI Discussion Paper Series 15-E-061, 1-36.

Rezvani, M., Khazaei, M. (2013). Prioritization of entrepreneurial marketing dimensions a case of in higher education institutions by using entropy. Int. J. Inf. Bus. Manag., 5(3), 30-51.

Roper, S., Du, J., Love, J. H. (2008) Modelling the innovation value chain. Res. Policy, 37, 961-977.

Sarwoko, E., Frisdiantara, C. (2016). Growth Determinants of Small Medium Enterprises (SMEs). Univ. J. Manag., 4(1), 36-41.

Schneider, E. (2015). U.S. Patent No. 8,990,347. Washington, DC: U.S. Patent and Trademark Office. 
Maziriri, E. T., Mapuranga, M. (2018). Modeling the nexus between entrepreneurial marketing dimensions and business growth among small and medium agro-processing enterprises in Zimbabwe. J. Agribus. Rural Dev., 2(48), 153-163. http://dx.doi. org/10.17306/J.JARD.2018.00407

Schreiber, J. B., Nora, A., Stage, F. K., Barlow, E. A., King, J. (2006). Reporting structural equation modeling and confirmatory factor analysis results: A review. J. Edu. Res., 99(6), 323-338.

Semrau, T., Ambos, T., Kraus, S. (2016). Entrepreneurial orientation and SME performance across societal cultures: An international study. J. Bus. Res., 69(5), 1928-1932.

Singh, R. K., Garg, S. K., Deshmukh, S. G. (2008). Strategy development by SMEs for competitiveness: a review. Benchmark. Int. J., 15(5), 525-547.

Sirmon, D. G., Hitt, M. A., Ireland, R. D. (2007). Managing firm resources in dynamic environments to create value: Looking inside the black box. Acad. Manag. Rev., 32(1), 273-292.

Sok, P., O'Cass, A., Miles, M. P. (2016). The performance advantages for SMEs of product innovation and marketing resource-capability complementarity in emerging economies. J. Small Bus. Manag., 54(3), 805-826.

Stam, W., Elfring, T. (2008). Entrepreneurial orientation and new venture performance: The moderating role of intra and extra industry social capital. Acad. Manag. J., 51(1), 97-111.

Tan, K. C., Kannan, V. R., Handfield, R. B. (1998). Supply chain management: Supplier performance and firm performance. Int. J. Purch. Mat. Manag., 34(3), 2-9.
Villanueva, J., Van de Ven, A. H., Sapienza, H. J. (2012). Resource mobilization in entrepreneurial firms. J. Bus. Vent., 27(1), 19-30.

Wambugu, A. W., Gichira, R., Wanjau, K. N., Mung'atu, J. (2015). The relationship between risk taking and performance of small and medium agro-processing enterprises in Kenya. Int. J. Econ. Comm. Manag., 3(12), 441-445.

Wang, T., Thornhill, S., De Castro, J. O. (2017). Entrepreneurial orientation, legitimation, and new venture performance. Strateg. Entrep. J., 1-20.

Wanjau, K. N., Gichira, R., Wambugu, A. W. (2016). Influence of Entrepreneurial Orientation on Firm Performance of Kenya's Agro Processing Small and Medium Enterprises. J. Bus. Manag., 18(19), 89-96.

Wiklund, J., Shepherd, D. (2003). Knowledge-based resources, entrepreneurial orientation, and the performance of small and medium-sized businesses. Strat. Manag. J., 24, 1307-1314.

Yang, M., Gabrielsson, P. (2017). Entrepreneurial marketing of international high-tech business-to-business new ventures: A decision-making process perspective. Ind. Market. Manag., 64, 147-160.

Zaefarian, G., Forkmann, S., Mitręga, M., Henneberg, S. C. (2017). A capability perspective on relationship ending and its impact on product innovation success and firm performance. Long Range Plann., 50(2), 184-199. 